\title{
Restoring Mill Creek: Landscape Literacy, Environmental Justice and City Planning and Design
}

\author{
ANNE WHISTON SPIRN
}

\begin{abstract}
Injustices occur when human law and social practice ignore natural processes and when those who plan, design and build the city focus on a neighbourhood's problems and fail to recognize its resources. The story of the Mill Creek neighbourhood in Philadelphia illustrates these themes. Mill Creek is shaped by all the processes at work in inner-city America. It was laid waste by the flow of water and capital, and by the violence of redevelopment and neglect. Known locally as 'The Bottom', Mill Creek is one of many such 'Black Bottoms' in the US. They are at the bottom, economically, socially and topographically. Here, harsh socio-economic conditions and racial discrimination are exacerbated by health and safety hazards posed by a high water table and unstable ground. Landscape literacy is a means for recognizing and redressing those injustices through urban planning and design and community development, just as verbal literacy was a cornerstone of the American Civil Rights movement of the 1950s and 1960s.
\end{abstract}

KEY WORDS: Landscape history, environmental education, community development, watershed management, urban design and planning

\section{Mill Creek}

The Mill Creek neighbourhood of West Philadelphia is a place of many puzzles. Within its street grid of three-storey brick rowhouses with small porches, are other types of dwellings: a Georgian mansion, single-family homes on large lots, tiny rowhouses with no yard and tall towers of concrete. The amount of open land in Mill Creek is striking, especially in contrast to the dense fabric of small rowhouses. Much open land is covered by rubble and grasses; in some places trees have grown 20 feet high. On some blocks, only one house or one small lot is vacant; in other areas, houses have sagging porches and crumbling foundations, and there are almost as many vacant lots as buildings. Blocks of vacant land and wasted structures border blocks of well-tended houses and gardens. Boarded-up storefronts speak of failed ventures, but other institutions, such as the numerous community gardens, flourish. Mill Creek is among the poorest neighbourhoods in

Correspondence Address: Anne Whiston Spirn, 36 Maolis Road, Nahant, MA 01908, USA. Email: spirn@mit.edu 
Philadelphia, yet it is home to many well-educated, middle-class residents; almost all are African-American.

To those who can read this landscape, it poses many questions. Why is there so much vacant land? Are there patterns to how and where abandonment occurs? Why are some parts of the neighbourhood so devastated, while others prosper? These are not trivial riddles. The answers reveal the nature of Mill Creek and are key to its future. When those who plan and build the city disregard the significance of these mysteries or fail to see them at all, they waste resources, produce dangerous, expensive mistakes and inflict grave injustice on all who live there.

The landscape of Mill Creek is a catalogue of the failures of 20th-century urban policy, planning and design. Some policies and projects were deliberate and insidious in their effects; most were well-intentioned but misguided. The Federal Housing Administration's guidelines for underwriters spelled out in the 1930s contributed to redlining, the practice of refusing to grant loans for the purchase of properties on the basis of location. ${ }^{1}$ Redevelopment projects of the 1950 s, such as the public housing towers inserted into this neighbourhood of small-scale rowhouses, had devastating effects on the place they sought to improve and contributed to the racial segregation of a neighbourhood where Blacks and Whites had lived next door to one another, in identical rowhouses, for at least a century. New playgrounds and streetscapes built in the 1960s cracked and sank within a few years of construction, and a public housing project was recently demolished.

The critics of modernist urban planning and redevelopment are now legion. However, much recent development in Mill Creek is likely to produce similar results. Like their predecessors, those responsible for planning Mill Creek often treat symptoms and fail to address the underlying processes that produce them. Planners too often concentrate on narrowly defined problems and fail to see the connections among seemingly unrelated phenomena. Designers tend to focus on physical form and fail to account for the processes that will continue to shape their project over time. Planners and designers alike see the devastation in Mill Creek, but are blind to the blocks of well-kept homes and miss the fact that one house type is never vacant. They do not see the 18th-century mansion; it is on no map or tour of Philadelphia's historic houses. Such prejudice is not limited to top-down planners and designers. Non-profit organizations dedicated to community reinvestment stress the neighbourhood's liabilities and neglect its resources and the opportunities these afford. Even grass-roots activists often concentrate on a specific local problem or a particular site and overlook how these fit into the larger neighbourhood, city and region.

To plan a neighbourhood is both a spatial and a temporal undertaking that entails the management of complex relationships, but planners' and designers' maps are usually static snapshots of current conditions, narrowly framed. Some problems, though manifest locally, are phenomena set in motion outside the neighbourhood and must be resolved in that context. Some features of the built landscape are clues to forces that continue to exert a decisive influence, while others are artefacts of processes now defunct. Some are amenable to change, others are not. Some are themselves dynamic agents that enable and constrain possibilities for subsequent development.

To restore the Mill Creek neighbourhood requires an understanding of how it came to be, how the built landscape evolved, through what processes and actions, 
when, and which of its features have had a sustained impact on their surroundings over time. I use the word landscape in its original sense in English and Nordic languages - the mutual shaping of people and place - to encompass both the population of a place and its physical features: its topography, water flow and plant life; its infrastructure of streets and sewers; its land uses, buildings and open spaces. ${ }^{2}$ The urban landscape is shaped by rain, plants and animals, human hands and minds. Rain falls, carving valleys and soaking soil. People mould landscape with hands, tools and machines, through law, public policy, the investing and withholding of capital, and other actions undertaken hundreds or thousands of miles away. The processes that shape landscape operate at different scales of space and time: from the local to the national, from the ephemeral to the enduring.

\section{Reading the Landscape of Mill Creek}

The landscape of Mill Creek is a textbook of American city planning and city building from the colonial period to the present. Market Street, the neighbourhood's southern boundary, is Philadelphia's main east-west axis and one of its oldest routes, laid as a western extension of William Penn's grid plan of 1683 for the centre of the city. The prevailing grid of streets in Mill Creek is an artefact of the 19thcentury streetcar suburb. The principal thoroughfares, Lancaster and Haverford Avenues, cut diagonally across the grid and predate it. Like Market Street, they once linked the city with its agricultural hinterlands; each points to a former ferry crossing of the Schuylkill River, one to Market, the other to Spring Garden. Lancaster Avenue was the nation's first turnpike, and before that an Indian trail that followed a ridgeline.

Mills powered by water operated along Mill Creek by 1711, and by the middle of the 19th century steam-powered textile mills were prominent. Wealthy Philadelphians established country estates on the outskirts of the city in the 18th century, such as Woodlands at the mouth of Mill Creek and Paul Busti's Blockley Retreat of 240 acres, established in 1794, which overlooked the creek upstream. Busti's estate was purchased in 1836 to establish a hospital in the country for psychiatric patients. That same year, a group of Quakers founded the Coloured Orphan Asylum on Haverford Avenue across the street from the Busti mansion. It was the first institution in the nation dedicated to the care of African-American children.

The Hopkins Atlas of 1872 shows the creek, hospital, home for orphans and mills within a grid of streets, houses and platted (but undeveloped) properties. This is a landscape undergoing rapid change from countryside to streetcar suburb. Although the neighbourhood's residents were predominantly White, enumeration tables of the 1880 US Census record that 'Blacks' and 'Mulattos' lived side by side with 'White' families. The Bromley Atlas of 1895 no longer shows the creek, and rowhouses have replaced the mill buildings at 46th and Haverford. In the Bromley Atlas of 1927, almost all the land north of Haverford has been developed, and the sinuous line of the sewer beneath blocks of rowhouses is the only visible trace of Mill Creek.

At first glance, the 17th-century forest and the 18th- and 19th-century agricultural and industrial landscapes seem obliterated, but abundant traces remain. From the corner of 46th and Haverford, one can read several hundred years of history. A large vacant block slopes upward toward the northeast. Once covered by homes, now it is 
a grassy meadow with a grove of ash and ailanthus trees. A fire hydrant amidst the trees is a clue to the houses that once stood here and to the pavement and pipes that lie beneath the soil. The processes of plant succession that shaped the original forest drive the growth of the grove. ${ }^{3}$ A high stone wall runs along the south side of Haverford Avenue, east to 42nd Street and west to 49th; it was built in the mid 19th century to enclose Pennsylvania Hospital's buildings, gardens and inmates. Uphill to the east, behind the stone wall of the old hospital, the roof of the Busti mansion is visible. It is now the Lee Cultural Center, which sponsors African-American cultural activities. Basketball courts and a playground occupy the former gardens.

There are painful stories in Mill Creek, stories just as important to remember as stories of mills and mansions. By the late 19th century, the creek was polluted by wastes from slaughterhouses, tanneries and households. In the 1880s, it was buried in a sewer, its floodplain filled in and built upon, but it still drains the stormwater and carries all the wastes from half of West Philadelphia and from suburbs far upstream. Each new suburb built in the watershed has poured more sewage and stormwater into the sewer. The size of the pipe-about 20 feet in diameter-is now far too small for the huge quantity of wastewater it must convey. So the water cracks the pipe, then undermines it, and, once or twice a year, sometimes more often, the sewer overflows, and brown water spouts from inlets and manhole covers.

For more than 60 years, the ground has fallen in, here and there, along the line of the sewer. The creek has undermined buildings and streets and slashed meandering diagonals of shifting foundations, and vacant land across the urban landscape. Local newspapers have chronicled the long series of broken pipes and cave-ins. ${ }^{4}$ In the 1940s, 47 homes were demolished because they were "plagued with rats and filled with sewer vapor". In 1945, a neighbourhood of small row homes built above the sewer was destroyed when the sewer collapsed. In 1952, a 35-foot-deep cave-in on Sansom Street swallowed two cars, and the porches of three homes crumbled into the crater. On 17 July 1961, the sewer caved in beneath Funston Street near 50th. Initially, four houses were destroyed and three people killed; ultimately 111 homes were condemned and demolished, leaving hundreds homeless and many others fearful of further collapse. "We haven't been ordered to leave. We're just too frightened to stay here", one person told a reporter. Months later, Philadelphia's Evening Bulletin described residents' complaints of sewer odours and their frustration at the city's slow response in repairing the 30-foot chasm. Entire city blocks are now open within the buried floodplain. Young woodlands of ailanthus, sumac and ash have grown up on older lots, urban meadows on lots vacated more recently. Many community gardens in this part of West Philadelphia lie within the old floodplain of Mill Creek; older gardeners remember when buildings sank, their foundations eroded by high groundwater, undermined by subsiding fill.

On higher ground are other types of vacant land, the product of the outward flow of capital and population. Vacant corner lots are common, remnants of the many corner stores that once served the neighbourhood. They are artefacts of changing scales and modes of merchandizing and the failure of new businesses to fill the gap. There are also individual, scattered vacant lots in otherwise intact blocks of homes, the consequences of events such as death and fire. Some lots were once 'heir houses', homes left vacant after the death of an owner when there was no clear title to the property; without active ownership, these homes fall into disrepair. ${ }^{5}$ Others were 
sites of fires, where homeowners with no insurance may have lacked the resources to rebuild. For many years, businessmen and homeowners in Mill Creek found it difficult or impossible to obtain fire insurance and mortgages. The Philadelphia Real Property Survey of 1934, a contributing factor to such insurance and lending practices, documented building age and condition, and the race, income and education of residents. Mill Creek's older houses, some in poor condition, some with flooded basements, and its population of different races and ethnic origins (some with relatively low incomes), led to the lowest rating, ' $D$ ' or 'red', for the entire neighbourhood.

In 1945 Pennsylvania enacted enabling legislation for federally funded redevelopment under the Urban Redevelopment Law. In 1948, the city designated the Mill Creek neighbourhood as a redevelopment area, and hired architect Louis Kahn to produce a plan. In 1950, following a sewer collapse near 47th and Fairmount Streets, Kahn was also commissioned to design the Mill Creek Housing Project on several square blocks near the cave-in. Newspaper articles from the 1950s to the 1960 s record protests by residents who opposed public housing, particularly the high-rise apartment blocks. The public housing was built, as were playing fields and ball courts on other blocks that had fallen in. Land immediately over the sewer pipe was maintained as open lawn or parking lots, but much of the new public housing was built on the buried floodplain. There have been no major cave-ins in recent years, but sinking streets, playgrounds and parking lots and shifting building foundations continue to plague the area. The basement of the elementary school built on the corner of 46th and Haverford in the 1960s is frequently flooded, and the building has sustained serious structural damage.

Between 1950 and 1970, the overall population of the Mill Creek neighbourhood declined by $27 \%$. In 1950 , the US Census described the population as about $27 \%$ Caucasian and 73\% African American. By 1960, the White population had dropped to about $13 \%$; it had dropped to $4 \%$ in 1970 , and to less than $2 \%$ in $1990 .{ }^{6}$ There are local reasons for these demographic changes, but they are also part of a much larger story. The city of Philadelphia, as a whole, also lost population during this period, and the trend continues. While six suburban counties around Philadelphia grew by as much as $12 \%$ in the 1990 s, Philadelphia lost $9 \%$ of its population during the same period (Diaz, 1999). This is a local manifestation of a national phenomenon, a massive migration from central cities to suburbs and ex-urban areas, which has reshaped American rural and urban landscapes, consuming farmland and forests and destroying urban communities in the process.

Given the outward flow of population and capital and the inward flow of sewage and groundwater, the abundance of vacant land and deteriorating or abandoned properties in Mill Creek is not surprising. The single feature of the Mill Creek landscape that has had the most significant, persistent and devastating effect is the least recognized: the floodplain of the creek itself and the hydrological processes that continue to shape it. And yet the strong pattern it creates - the band of open land and deteriorating buildings - is striking once recognized. Outside the buried floodplain, there is another locus of widespread abandonment and deterioration. The area between 48th Street and Lancaster Avenue is riddled with boarded-up houses and abandoned blocks of land; it contains some of the oldest and smallest houses, as well as the most recent, the Mill Creek Public Housing. 
Just as significant as the devastated areas are locales where little or no abandonment occurs. Perhaps these intact blocks are even more significant for their survival, given the strong destructive forces operating on Mill Creek's landscape. In the neighbourhood west of 48th Street, there are many signs of private investment: well-maintained homes with front porches furnished with chairs and potted plants. Among the predominant small rowhouses of brick are blocks of slightly more substantial rowhouses, some with fine architectural details: bands of elaborate brickwork on facades, ceramic tiles and parquet floors in the interior. One type of block seems never to have vacancies: the stone-faced, two-storey rowhouses with front gardens, each with a garage under the house, the only house type that was built with off-street parking. There are few vacancies outside the buried floodplain; small open lots have been transformed into private gardens or off-street parking, larger ones into community gardens, like Aspen Farms at 49th and Aspen Streets, which often wins the prize for 'best community garden' in an annual city-wide contest.

Why did the area west of 48th Street remain relatively intact, outside the floodplain, while other parts of the neighbourhood declined more radically? Blocks in this part of Mill Creek received the same rating of highest risk as the rest, and they were likewise subject to redlining. One major factor is that they were buffered from such land uses as slaughterhouses and stables that clustered near Lancaster Avenue. Another factor may be the scale, quality and style of the homes that were built. They are sufficiently large to accommodate the needs of modern families, but even the more substantial homes are small enough to maintain on a modest income. As the population has declined, the most desirable housing has remained attractive to homeowners and has been sustained, while the least desirable seems to have been abandoned more readily.

The landscape of Mill Creek is full of dialogues and stories, from epics to folklore to cautionary tales. To read this landscape is to understand that nothing stays the same, that catastrophic shifts and cumulative changes shape the present. It permits the reader to see what is not immediate: a former store in a vacant corner lot; a future forest in today's meadow; water underground in the cracks of a building's foundation; the slumps in pavement. To read landscape is also to anticipate the possible, to envision, choose and shape the future: to see, for example, the connections between buried, sewered stream, vacant land and polluted river, and to imagine rebuilding a community while purifying its water.

\section{The West Philadelphia Landscape Project}

For the past 18 years, I have worked in and studied Mill Creek: first, from 19871991, as part of a larger landscape plan and 'greening' project for West Philadelphia; then, since 1994, as the primary focus of my research on urban landscape planning and community development. The first stage was an extension of my work on the role of urban nature in city design and planning (Spirn, 1984, 1985, 1986, 2000). I focused initially on vacant land as a resource to restore the urban natural environment and rebuild inner-city neighbourhoods, then broadened my investigation to explore how to combine a comprehensive, top-down approach with a grassroots, bottom-up approach to urban planning and design (Spirn, 1991). 
Vacant urban land is a social, environmental and aesthetic problem, a symbol of neglect and decay, but it is also a resource for reshaping the Mill Creek neighbourhood to serve the needs of its residents and to address regional problems. Vacant lots relieve the former density and provide space for new uses and the opportunity to correct past mistakes. There is an impulse, particularly among residents of Mill Creek, to rebuild houses, but there is no housing shortage in the city of Philadelphia, whose shrinking population and large proportion of ageing homeowners mean there will continue to be a surplus of houses for the foreseeable future (Ferrick, 1997). In any case, houses should not be rebuilt on much of the vacant land in Mill Creek. Although the former creek bed is buried, the valley bottom still functions as a floodplain, where the soil is sometimes saturated. A key proposal of the West Philadelphia Landscape Project is to manage the buried floodplain as part of a broad approach to planning the city's watersheds and as a strategy to secure funds to rebuild the neighbourhood.

Normally, as rain falls, it flows quickly across the paved urban floodplain to the sewer, then on to a treatment plant for cleansing before discharge into the Schuylkill River. After a heavy rain, there is too much stormwater, and some flows directly into the river-a combined sewer overflow. Such overflows are a significant source of water pollution, and the US Environmental Protection Agency has pressured the City of Philadelphia to eliminate them. This will require millions of dollars, and there are funds available to support innovative approaches. Why not use low-lying vacant blocks in Mill Creek to detain stormwater in order to eliminate combined sewer overflows from the watershed? It is not feasible to bring the creek back above ground; it is now a sewer that carries waste as well as stormwater, but its presence as a green ribbon of parks and play fields would recall the creek, protect houses from flooding and provide local open space for a variety of public and private uses. This is not a radical proposal, but an application of well-accepted watershed planning practice to an urban watershed. In 1985, I made a similar proposal in Boston (Spirn, 2000). In Philadelphia, the timing was opportune, with ample time to lay the groundwork before the City Planning Commission produced its plan for West Philadelphia in 1994.

By the end of the first phase of the project in 1991, my students, colleagues and I had created a digital database with maps of the neighbourhood's demographics and physical features, made proposals for the strategic reuse of vacant urban land in the Mill Creek watershed, and designed dozens of gardens (including new common space for Aspen Farms). The West Philadelphia Landscape Plan: A Framework for Action (Spirn, 1991) provides an overview of the project during that initial period and describes the core recommendations. ${ }^{7}$ The project is fundamentally academic, and there is no client in the conventional sense. Although the work is not bound by political expedience, it has no official standing. We built demonstration projects, but had no authority to implement plans.

During the first phase of the project (1987-1991), and for years following, I hoped to convince the City Planning Commission and the Philadelphia Water Department that the buried creek was both a force to be reckoned with and a resource to be exploited. My research assistants and I presented our work to the Director of the Philadelphia City Planning Commission in 1991. An article in the Philadelphia 
Inquirer the following year summarized the proposals and urged the city to adopt them (Hine, 1992). In 1993, Living on Earth, a programme on National Public Radio, broadcast a story on the West Philadelphia Landscape Project. I was confident that the work would influence the city's plan for West Philadelphia. It did not.

When the City's Plan for West Philadelphia was published in 1994, it failed to mention the buried floodplain and the hazards it posed. In 1994, part of the Mill Creek neighbourhood was designated a federal Empowerment Zone, under whose auspices new housing and businesses were proposed for locations on the buried floodplain. That year, the city donated a large parcel of vacant land for the construction of subsidized housing for first-time, low-income homeowners. This latter project, which was jointly sponsored by the city and by the Nehemiah Corporation, was especially troubling. The site was on the buried floodplain, and the project was designed as an enclave. Not surprisingly, the buyers of those homes report that they have little or no contact with the larger Mill Creek community (Cummings et al., 2002). Had the developers chosen a site on vacant land next to blocks of well-maintained homes, the new residents could have been integrated into the neighbourhood and into an existing network of homeowners. This also would have bolstered the investments of time, energy and money already made by residents.

When the West Philadelphia Landscape Project began in 1987, I did not intend a long-term involvement. However, the City Planning Commission's disregard for the health, safety and welfare of Mill Creek residents made me renew my commitment. It also prompted new realizations that both sharpened and enlarged the questions my research sought to answer. Confronted with scepticism about the existence and dangers of the buried floodplain, I began to understand this resistance as a form of prejudice and a kind of illiteracy - an inability on the part of public officials, developers and even Mill Creek residents themselves to read the landscape.

I organized my teaching and research to explore these issues. From 1994-2001, students in my classes at the University of Pennsylvania and at the Massachusetts Institute of Technology analysed the urban watershed, demonstrated how stormwater could be collected in landscape projects that are also stormwater detention facilities, and created dozens of designs for wetlands, water gardens and environmental study areas on vacant land in the Mill Creek neighbourhood. ${ }^{8}$ In 1995, research assistants expanded and redesigned the digital database so that it could run on personal computers. We hoped to make the database accessible to local organizations and residents. ${ }^{9}$ When the West Philadelphia Landscape Project website was launched in early 1996, it featured the database, reports and built projects of $1987-1991$. Since then, it has been a showcase for ongoing work. ${ }^{10}$

In 1994 my students and I launched a programme with a public school in the Mill Creek neighbourhood in order to reach a broad spectrum of the Mill Creek population and also to bring together children and the elder gardeners with whom I had worked since 1987. What began as a community-based, environmental education programme organized around the urban watershed grew into a programme on landscape literacy and community development. In the process, I learned that the consequences of illiteracy are far greater than I had imagined. 


\section{Teaching and Learning Landscape Literacy: The Mill Creek Project}

From 1996 to 2001, hundreds of children at Sulzberger Middle School, together with dozens of my students at the University of Pennsylvania (Penn), learned to read the neighbourhood's landscape; they traced its past, deciphered its stories and told their stories about its future, some of which were built. The tools they used were their own eyes and imagination, the place itself, and historical documents such as maps, photographs, newspaper articles, census tables and redevelopment plans. The programme had four parts: reading landscape, proposing landscape change, building landscape improvements and documenting these proposals and accomplishments. The first two parts were incorporated into university and middle-school curriculum during the academic year; all four were integrated in a four-week summer programme.

I chose Sulzberger Middle School for several reasons. Children in sixth through eight grades (11-13 year olds) are old enough to grasp relatively sophisticated ideas and to work on landscape construction projects and young enough for an educational experience to have an important influence. ${ }^{11}$ The school's location was ideal. Aspen Farms Community Garden is just a block away, and the gardeners were keen to participate. Front and back doors of the school open on different worlds. The front doors look out on the high ground of the old floodplain terrace and faces the neighbourhood of homes around Aspen Farms. The cafeteria and gym, several metres lower, are in the bottomland; so is the playground and the Mill Creek Housing Project across the street. I was warned that Sulzberger was shunned by many teachers in the Philadelphia School District; its reputation seemed to stem from students' weak performance on standardized tests (among the worst of all schools in the city) and the fact that Mill Creek is among the city's poorest neighbourhoods. Like the residents of Mill Creek, all the students (and most teachers) are African-American. The principal initially was reluctant to work with me, but was persuaded by the sponsorship of Penn's Center for Community Partnerships and the Aspen Farm gardeners. It took two years of small collaborations to lay the groundwork for a more ambitious programme.

At the start of the first year of the expanded programme in fall 1996, a Sulzberger teacher told me that her students called their neighbourhood 'The Bottom'. So they already know it is in a floodplain? "No, they mean it's at the bottom." Both meanings of the word can be read into the area around Sulzberger School: standing water after rain; slumping streets and sidewalks; vacant house lots, rubble-strewn; whole square blocks of abandoned land; men standing around street corners on a workday afternoon, jobless.

The school's environmental curriculum treated at length such topics as tropical rain forests and exotic wildlife, while issues of local importance like watersheds and plant succession received scant attention or none at all. One popular science teacher took students once a year to an environmental centre in the suburbs to see and study Nature. To change the teachers' and students' perceptions that the Mill Creek landscape was divorced from the natural world was quite a challenge. It was equally hard to persuade students that their neighbourhood had ever been different or that it might be changed. 
In fall 1996 my students taught weekly workshops on Mill Creek and its urban watershed. They led a field trip outside the school to look for signs of the buried creek (slumping sidewalks, cracks in walls, manhole covers). One eighth-grade teacher followed up with further assignments, including an essay on the buried creek, the problems it posed and ideas for solutions. The students did what was asked of them, but the creek was not yet real to them. When my students spoke of designs for change, the children told them all the reasons the proposals would fail. "It won't happen." "Someone will wreck it." Studying the history of the neighbourhood proved to be the key that unlocked the students' imagination.

"You mean, there really was a creek!?" a 13 year old exclaimed in April 1997 as she examined a photograph from 1880 showing stream, mill, workmen dwarfed by the huge sewer they were building, and new rowhouses in the distance. This breakthrough in her understanding came six months into the Mill Creek Project. The catalyst was a series of weekly classes taught by students in my seminar. Each of my students led a group of six or seven eighth graders in 90-minute workshops. The sessions focused on particular time periods. There were no lectures and no secondary sources. At the end of every class, two students from each group 'reported out' by telling the rest of the class what they had discovered. The groups looked at different primary documents and/or emphasized a different theme in order to provide a variety of topics for the reporting out.

My students brought in texts, tables of statistics, maps and photographs, and then asked the eighth graders to describe and compare them. To help the children draw out meanings from the documents, they posed successive questions. By breaking up big questions into smaller questions to which the Sulzberger students could find answers, my students led them to develop a hypothesis and then to find further evidence to support it. Only after the children had identified potential explanations for what they had observed, did my students tell them about background information that they had gleaned from their own reading and from our seminar discussions. The idea was to encourage the children to form the habit of looking for significant detail, framing questions and reasoning out possible answers. The goal was that, after reading these documents describing the history of their neighbourhood, the students would transfer this process to the reading of the landscape itself. ${ }^{12}$

During the first class at Sulzberger, the Penn students introduced the concept of a primary document. "Where do the authors of your history textbook get the information they write about?" "From books." "And where do the authors of those books get their information?" "From other books?" "What about the sources for those books?" One by one, the Penn students presented a time line composed of events in Mill Creek's history, each represented by a document of the period: a 17thcentury map of the Delaware Valley showing a river in the midst of forest, an 18thcentury engraving of a Leni Lenape Indian village, a map of 1872 showing several mills along Mill Creek, a photograph of the Mill Creek sewer under construction in the 1880s, Louis Kahn's plan for the redevelopment of the neighbourhood in 1954, a newspaper report of the sewer's collapse in 1961, the Empowerment Zone proposal of 1994. When we arrived at the school the following week, the eighth graders had mounted the documents on red construction paper, laminated them in a protective coating of plastic, and posted them, 20 in all, on the wall of the hallway outside their 
classroom, where they remained until the end of the school year, prompting much comment by teachers, parents and other students.

The Sulzberger students' interest intensified as the time period under discussion got closer to the present. The class on the period from 1930 to 1970 was a turning point. My students were apprehensive, for they anticipated that the Sulzberger students would be angry about the effects of redlining and urban renewal on the neighbourhood. They asked the children to play the role of a neighbourhood council in 1961; each group was a sub-committee charged with investigating an important issue. The groups presented their findings to the entire class and recommended actions to be taken, which then were discussed and voted on. One group investigated the origins of the 1961 cave-in and how to prevent future catastrophes. They read newspaper articles, studied maps and photographs, and learned that the cave-in was one of many that had occurred along the Mill Creek sewer since the 1930s. A second group reviewed Louis Kahn's redevelopment plan and his design for Mill Creek Public Housing. They were particularly impressed to learn that Kahn was a famous architect. The students marked up a copy of Kahn's plan and coded it with different colours to illustrate their recommendations that the neighbourhood council should support some features and oppose others.

A third group looked into how homeowners and small businesses might obtain loans for mortgages and improvements. They read the Home Owners Loan Corporation (HOLC) criteria for rating neighbourhoods and studied the maps in the Philadelphia Real Property Survey of 1934, which showed every block in Mill Creek, except for the cemeteries, as highest risk, and learned the meaning of redlining. Their response to the HOLC report, maps and lending practices surprised me. They showed no anger. Their faces registered surprise, then relief, then determination to come up with an effective response: a city-wide march on city hall and the establishment of a community bank.

The students' energy carried over into the next class, which focused on planning for the future. Staff members from the West Philadelphia Empowerment Zone and the City Planning Commission visited the class. Sulzberger students asked the planners: "Why did you let those new houses be built on the buried floodplain? Did you warn the people who bought them?" "What are you doing about the Mill Creek sewer?" "What have you done about redlining?" "Why haven't you started a community bank?"

Between our weekly visits, the Sulzberger teacher took the material we brought in and used it across the curriculum in social studies, maths, science, English and art. He reported, for example, that the class spent an entire day analysing census statistics from 1860 to 1990 . They were particularly fascinated to learn that African Americans had lived in the neighbourhood since at least 1860, and that many White people also had lived there for most of the 19th and 20th centuries. And they turned to their American history textbook with greater interest than they had shown previously.

Landscape literacy entails more than reading, it means shaping landscape also. Each student made a proposal for how the creek might be transformed from a liability into a neighbourhood asset. These were published at the end of the school year in a booklet with one-sentence reviews by the Mayor of Philadelphia, among others. ${ }^{13}$ 
At the end of April, the Sulzberger students and their Penn mentors gave a public presentation on the history of Mill Creek at a symposium held at the University of Pennsylvania. After the presentation, someone asked what was the most important thing they had learned. One 13 year old answered for the whole class: "We learned to be proud of our neighborhood. I want to stay there and help make it a better place".

At the beginning of the semester, Sulzberger students described their neighbourhood in negative terms and said they would not live in Mill Creek if they had a choice. Only one student planned to attend college. Two months later, all but one student said they planned to attend college. The teacher reported that his students' performance in all subjects had improved dramatically. He attributed this to the way that primary materials challenged and made history real for them and to their growing perception of how their own lives and landscape were related to the larger city, region and nation.

Teaching and studying the landscape of Mill Creek also caused learning to become real for my students. ${ }^{14}$ Most were unprepared for what they observed: the sheer extent of devastation in the Mill Creek landscape, for example, and the high level of intelligence among the children. My students' weekly journals revealed their evolving understanding of race and place. After several visits to Sulzberger, many acknowledged their surprise that some of the Sulzberger students were smarter than they, and this led them to reflect on their own prejudice and privilege. They also reported that their experiences in Mill Creek challenged the assumptions and theories asserted by texts that they were reading for other courses.

The culmination of the year was a four-week summer programme for Sulzberger students and teachers, organized and led by four of my research assistants. ${ }^{15}$ In the mornings, the group met either at Aspen Farms, where they built a water garden and outdoor classroom, or at Sulzberger, where they constructed a topographic model of the Mill Creek watershed and learned how to create a website. Two students from the eighth-grade class worked as junior counsellors in the mornings and, in the afternoons, as research assistants at the university, where they wrote, illustrated, designed and produced 'SMS News', a series of web pages that were posted on the West Philadelphia Landscape Project website. ${ }^{16}$ The four Sulzberger teachers also spent afternoons at the university; one research assistant taught them web authoring and how to use GIS (geographic information systems) software to map the neighbourhood. At the end of the summer, one of these teachers was appointed to head the school's new computer programme.

The Mill Creek Project continued in subsequent years with a similar format of weekly workshops led by Penn students during the academic year and a four-week summer programme in July based at the school and at Aspen Farms. ${ }^{17}$ In 1998, the Sulzberger principal and teachers decided to expand the programme, wrote grant proposals, and obtained funds to do so. They established four small learning communities, each with 10 teachers and about 250 students; one focused on the themes of regional watershed and local community. Each class was required to design and carry out a community service project every year: to identify problems in the community and to bring these problems and potential solutions to public attention. The computer teacher created an after-school computer club and worked with the staff of Penn's Center for Community Partnerships to secure grants for the 
purchase of equipment and software. Within two years, members of the computer club were taking apart and building computers and writing computer code to adapt commercial software.

\section{Putting Mill Creek on the Map}

From 1998, Sulzberger Middle School and the Mill Creek Project received increasing local, national and international recognition. ${ }^{18}$ Philadelphia School District staff, politicians and officers from national foundations visited the school and observed Sulzberger and Penn students in the classroom. The Sulzberger portion of the West Philadelphia Landscape Project website led Pennsylvania's governor to invite students from Sulzberger to make a five-minute presentation to the State Legislature; their presentation was televised, as was the legislature's response-a long, standing ovation. Later that year, the Philadelphia School District named Sulzberger 'School of the Month' and produced a television documentary on the Mill Creek Project and the school's innovations. In 1999 Sulzberger was the subject of a report on NBC Evening News, a national television programme. In 2000, President Bill Clinton visited the school.

Recognition for the Mill Creek Project and for Sulzberger opened doors to other collaborations. In 1999, the Mill Creek Coalition, a group of neighbourhood organizations, invited me to work with them on the creek and its impact on the community, including research on flooded basements and a course for residents on the history of Mill Creek's landscape. ${ }^{19}$

From 1996 to 1999, there were over a million visits to the West Philadelphia Landscape Project website from more than 90 countries on six continents. Among those who visited were public officials. In fall 1996, staff of the US Environmental Protection Agency invited engineers at the Philadelphia Water Department to meet with me to discuss the potential of stormwater detention to reduce combined sewer overflows. ${ }^{20}$ At that time, the Mill Creek watershed did not even appear on the maps the Water Department was using, but was subsumed under the much larger watershed of the Schuylkill River. They agreed to put Mill Creek on the map as a special study area. In 1999, staff from the Water Department asked me to take a group of engineers on a field trip to Mill Creek. With 19th-century maps in hand, we walked and drove along the buried floodplain and looked at potential sites for stormwater detention projects. An immediate outcome of this trip was the decision to build a demonstration project on a vacant block next to Sulzberger, which would detain stormwater and also function as an environmental study area and outdoor classroom for the school. The Water Department obtained a grant to fund the project in 2000 and pledged to work with teachers and students at Sulzberger. They hired one of my research assistants to direct the project and, in 2001, co-sponsored the summer programme on the urban watershed with Sulzberger Middle School. ${ }^{21}$ Later that year, the Philadelphia Water Department, Philadelphia Housing Authority and the Philadelphia City Planning Commission submitted a proposal for \$34.8 million to the US Department of Housing and Urban Development's Hope VI Program in order to redevelop Mill Creek Public Housing as a demonstration project that would provide an environmental study area for the school and integrate stormwater management measures to reduce combined sewer overflows. The city 
cleared the site in November 2002 and broke ground in August 2003 on a $\$ 110$ million project.

A few years ago, I was confident that things were going well for Mill Creek. I had moved from the University of Pennsylvania to the Massachusetts Institute of Technology in fall 2000, but continued to work with teachers at Sulzberger. Students in an MIT class travelled to Philadelphia, collected stories about the project from various participants, and redesigned the West Philadelphia Landscape Project website. In 2002, the computer teacher at Sulzberger visited MIT in order to discuss plans for further collaboration. Then, a few months later, the Commonwealth of Pennsylvania took control of the Philadelphia School District and granted responsibility for the management of Sulzberger, among other schools, to a corporation headquartered in New York. After trying to work with corporation staff that summer, the computer teacher and the other key teacher in the Mill Creek programme resigned in protest of certain new policies. ${ }^{22}$

In November 2004, I learned that the Philadelphia Streets Department had refused to grant a permit for the city's demonstration project in Mill Creek. New houses would be built, but the programme to integrate stormwater management to improve water quality had been abandoned. The professional consultants whom the city hired to prepare the plan chose not to fight the decision, nor did they alert those who might have intervened in the political process more effectively.

Putting Mill Creek on the map and keeping it there is not easy, whether the creek itself, the neighbourhood, or the people who live there. Confronting these recent failures, I sometimes think of the children's initial scepticism about prospects for change: "It won't happen... . Someone will wreck it". And this makes me determined to find a way to continue.

\section{Environmental Justice, Landscape Literacy and City Planning and Design}

Mill Creek is shaped by all the processes at work in inner-city America. The neighbourhood was laid waste by the flow of water and capital and the violence of redevelopment and neglect. The correlation of a buried creek with deteriorated buildings and vacant lands in inner-city neighbourhoods is not unique to Philadelphia; similar situations are found in many other American cities (Spirn, 1986, 2000). Mill Creek is typical of many American inner-city neighbourhoods where the residents are predominantly low-income people of colour. Known locally as 'The Bottom', it is one of many such 'Black Bottoms' in the US. They are at the bottom, economically, socially and topographically. Here, harsh socio-economic conditions and racial discrimination are exacerbated by health and safety hazards posed by a high water table and unstable ground.

Despite such conditions, the landscape and population of these communities embody resources as well as problems. In Mill Creek, the resources are many and varied. Flourishing community gardens demonstrate the energy and determination of the gardeners who reclaimed them from abandoned lots; flowers planted along the sidewalk and bags of vegetables offered there express the gardeners' generosity. Inside Sulzberger Middle School, the drawings, models and essays that decorate the halls speak of young people's intellect and vision. Lancaster Avenue, the stone wall that runs for blocks along Haverford Avenue, and the many different types of 
houses, from the Georgian mansion to the tiny rowhouse, are landmarks that make the past visible and change tangible. Even vacant blocks and the buried floodplain are potential resources. To recognize resources is not to deny the problems, but to see each in the context of the other.

These resources are readily apparent once the observer is prepared to see them. Someone who knows neither local history nor the broader canvas of US urban history is unable to read many of the stories the landscape holds. One who assumes that the city has supplanted 'nature' is not likely to see the effects of the natural processes that still shape its landscape; another who believes that the city has degraded 'nature' is apt to see only pollution. Those who think the ravaged state of a neighbourhood is the natural outcome of its occupation by an isolated 'underclass' who have lived in poverty for generations, may see only devastation. Prejudice is reinforced by the tools professionals use. If those responsible for planning and designing a neighbourhood rely only on maps of those features they judge to be important and do not spend time there, their assumptions are not likely to be contradicted. Mistakes that follow from misreading or failing to read significant features of the urban landscape can have terrible consequences.

Ten years ago, I thought that the worst effect of landscape illiteracy was to produce environmental injustice in the form of physical hazards to health and safety. The Sulzberger students showed me that there is an even greater injustice than inequitable exposure to harsh conditions: the internalization of shame in one's neighbourhood. This is a particularly destructive form of injustice. To feel both at home in a place and ashamed of it is harmful. It saps self-esteem and can engender a sense of guilt and resignation. Before the students at Sulzberger Middle School learned to read their landscape more fully, they read it partially. Without an understanding of how the neighbourhood came to be, many believed that the poor conditions were the fault of those who lived there, a product of either incompetence or lack of care. Learning that there were other reasons sparked a sense of relief. Once they had the skill to read the landscape's history, they began to see their home in a more positive light, came to appreciate the effort and vision that places like Aspen Farms represent, and to regard some adults, like the gardeners, as heroes. They came to consider the possibility of alternative futures and brimmed with ideas. Secure in their knowledge and ability to reason, they challenged public officials with confidence and impressed them with articulate proposals. To read and shape landscape is to learn and teach: to know the world, to express ideas and to influence others.

Verbal literacy - the ability to read and write - is commonly acknowledged as an essential skill for the citizen to participate fully and effectively in a democratic society. Teaching literacy became a cornerstone of the American Civil Rights movement of the 1950s and 1960s. The 'Citizenship School', which began as a means to increase voter registration through the promotion of literacy, evolved into a forum for discussion and a catalyst for political action (Horton \& Freire, 1990). When, I first read about Horton's work with civil rights activists and Freire's with adult literacy programmes in Brazil, I was struck by the many parallels to my experience with landscape literacy in Mill Creek.

Freire designed literacy programmes that were tailored to what he calls the 'word universe' of the learners. To extract the words specific to the universe of particular 
people and place, and as a preparation for reading the word, he employed images of their surroundings. He found that "decodifying or reading the situations pictured leads [people] to a critical perception of the meaning of culture by leading them to understand how human practice or work transforms the world" (Freire \& Macedo, 1987, p. 36). He believes that people should learn to read in the context of the "fundamental moments of their common history" and proposes that texts of local history be created for that purpose from transcripts of taped interviews with older inhabitants (Freire \& Macedo, 1987, p. 45). In Literacy: Reading the Word and the World, Freire and Donaldo Macedo describe literacy as a form of cultural politics that either "serves to reproduce existing social formations" or "promotes democratic and emancipatory change" (Freire \& Macedo, 1987, p. 141) They assert that knowledge of the world is a precondition for literacy and that understanding and transformation of the world should be its goal. Reading, they say, "always involves critical perception, interpretation, and the rewriting of what is read" (Freire \& Macedo, 1987, p. 36). Macedo suggests that "emancipatory literacy" has two dimensions:

On the one hand, students have to become literate about their histories, experiences, and the culture of their immediate environments. On the other hand, they must also appropriate those codes and cultures of the dominant spheres so they can transcend their own environments. (Freire \& Macedo, 1987, p. 47)

Studying their neighbourhood's natural and built features brought the place alive for the Sulzberger students. The understanding of their own landscape also opened wider vistas. It introduced them to broader social, political and environmental issues and promoted other learning. In Freire's terms, it enabled the "students to develop a positive self-image before grappling with the type of knowledge that is outside their immediate world.... It is only after they have a grasp on their world that they can begin to acquire other knowledge" (Freire \& Macedo, 1987, p. 128).

Like verbal literacy, landscape literacy is a cultural practice that entails both understanding the world and transforming it. One difference between verbal literacy and landscape literacy, however, is that many professionals responsible for planning, designing and building the city are not landscape literate. After six weeks' investigation of the history of their neighbourhood, the children were more literate than many professionals, and some of their proposals for the neighbourhood were more astute. To be literate is to recognize both the problems in a place and its resources, to understand how they came about, by what means they are sustained, and how they are related. Such literacy should be a cornerstone of community development and of urban planning and design. To plan prudently is to transform problems into opportunities and liabilities into resources, and to intervene at an appropriate scale. To design wisely is to read ongoing dialogues in a place, to distinguish enduring stories from ephemeral ones, and to imagine how to join the conversation. The stakes are high for those who must live in the places professionals help create. Like literacy, urban planning and design are cultural practices that can serve either to perpetuate the inequities of existing social structures or to enable and promote democratic change. 


\section{Acknowledgements}

Many debts are incurred during a project of such a long duration. A list of sponsors and participants apppears on the West Philadelphia Landscape Project website (http://web.mit.edu/wplp). The initial support of the J.N. Pew Charitable Trust from 1987 to 1991 made possible the foundation from which all later activities grew. Without the support of the Center for Community Parnerships at the University of Pennsylvania, the work with Sulzberger Middle School would not have been possible; support ranged from the provision of vans to ferry my students back and forth to seed grants for curriculum development to support for research assistants. To learn more about the Center, whose leadership in promoting academically-based community service has received international recognition, see http://www.upenn. edu/ccp. I am grateful to Kenneth Olwig for editorial suggestions and would also like to acknowledge Cynthia Ott, who assembled a rich archive of historical material, first as a student, then as a research assistant.

\section{Notes}

1 The racial composition of a neighbourhood was one of several criteria used for assessment. For an excellent discussion of research on redlining, both historical and current, see Hillier (2003).

2 English dictionaries define landscape as static and "natural": "a picture representing a view of natural scenery (as fields, hills, forests, water) ... a portion of land that the eye can comprehend in a single view" (Merriam-Webster, 2003). But landscape is not a mere visible surface, static composition, or passive backdrop to human theatre. Landscape associates a place with all who dwell there, past and present. Danish landskab, German landschaft and Old English landscipe combine two roots. 'Land' means both a place and the people living there (earth, country, nation). Skabe and schaffen mean "to shape"; suffixes -skab and -schaft, as in the English '-ship', also mean association, partnership. Still strong in Scandinavian and German languages, these original meanings have all but disappeared from English. See Spirn (1998) for a longer discussion.

3 A ballfield was recently built here, so the meadow and grove are no more.

4 These articles were collected and compiled by Heather Hillman (Hillman, 1997).

5 This is a vernacular term explained to me by Frances Walker, a resident of Mill Creek.

6 Population of Hispanic origin was less than $1 \%$ in 1990.

7 In addition to built projects, there are five reports. Models of Success: Landscape Improvements and Community Development describes examples of successful projects that have already been built and draws lessons for similar projects that could be undertaken in West Philadelphia (Spirn \& Marcucci, 1991). This Garden is a Town explores community gardens as models for neighbourhood-based planning (Spirn \& Pollio, 1990). Shaping the Block focuses on the block as a significant unit of neighbourhood and explores how residents can reshape the block they live on to better support their needs (Spirn \& Cameron, 1991). Vacant Urban Land: A Resource for Reshaping Urban Neighborhoods describes the diverse types of vacant urban land that occur in West Philadelphia and how they can be reclaimed for a variety of uses (Spirn \& Pollio, 1991). The West Philadelphia Digital Database: An Atlas and Guide is an introduction to the digital database (Spirn \& Cheetham, 1996).

8 Many of these can be seen on the web pages for my studio class Transforming the Urban Landscape in 1996, 1997 and 1998 (http://web.mit.edu/wplp/course).

9 Examples of maps and other information from the digital database are online at http://web.mit.edu/ wplp/wpdd/wpddhome.htm.

$10 \mathrm{http} / /$ web.mit.edu/wplp. To see the original website, click on the link to Old Penn WPLP. The website was redesigned by my MIT students in 2002; to see their version, go to New MIT WPLP.

11 One goal was to inspire students to enter high school with their sights set on a college education and with the confidence that this ambition was achievable. 
12 The students in spring 1997 spent the first six weeks of the 14-week semester preparing for their visits to the Sulzberger classroom. Each student researched one period in the neighbourhood's history from pre-colonial times to the present, found primary sources, and used secondary texts to put the history of the neighbourhood into the context of region and nation.

13 The texts and drawings of this report, Power of Place: Essays about Our Mill Creek Neighborhood, are on the WPLP website, as are the reflections of Sulzberger teacher Glenn Campbell.

14 Those enrolled were typically undergraduates and graduate students. Initially, the students in the class were Caucasian or Thai; in later years, the ethnic and racial diversity broadened to include Hispanic, African-American and Asian-American students.

15 Martin Knox, one of the research assistants who led the summer programme in 1997, spoke in 2002 with my MIT students. His reflections are online at http://web.mit.edu/4.243j/www/wplp/s-knox.html

16 SMS News is online in the Sulzberger (SMS) part of the WPLP website at http://web.mit.edu/wplp/ sms/smsnews/smsnew.htm

17 More information about and illustrations of the Mill Creek Project are available online at http:// web.mit.edu/wplp/sms/millc.htm

18 Some of these are described online at http://web.mit.edu/wplp/sms/award.htm

19 A description of these activities appears on the WPLP website at http://web.mit.edu/wplp/project/ mccoal.htm and http://web.mit.edu/4.243j/www/wplp/s-cornitcher.html

20 Joe Piotrowski, Associate Director of the Environmental Protection Agency's Water Division, Region 3, describes the Environmental Protection Agency's role in the project at http://web.mit.edu/4.243j/ www/wplp/s-piotrowski.html

21 My former research assistant, Sarah Williams, and Joanne Dahme, Watersheds Programs Manager at the Philadelphia Water Department, describe their experiences with this programme at http:// web.mit.edu/4.243j/www/wplp/stories.html

22 Reportedly, the final straw was when the corporation placed in charge of Sulzberger decided to partly dismantle Sulzberger's computer lab in order to distribute equipment to other schools that did not have as many computers.

\section{References}

Cummings, J. L., DiPasquale, D. \& Kahn, M. E. (2002) Measuring the consequences of promoting inner city home ownership, Journal of Housing Economics, 11, pp. 330-359.

Diaz, M. (1999) Philadelphia loses 9\% of its population, Philadelphia Inquirer, 1 July.

Ferrick, T. (1997) Graying homeowners, a new city woe, Philadelphia Inquirer, 15 September.

Freire, P. \& Macedo, D. (1987) Literacy: Reading the Word and the World (Westport, CT: Bergin \& Garvey).

Hillier, A. E. (2003) Spatial analysis of the historical redlining: a methodological approach, Journal of Housing Research, 14(1), pp. 137-167.

Hillman, H. (1997) Urban redevelopment and the Mill Creek neighborhood: 1930-1975. Unpublished paper for Urban Studies 320. Water, Schools, and History, University of Pennsylvania, Philadelphia, PA.

Hine, T. (1992) Surroundings: a long-buried creek in west Philadelphia, Philadelphia Sunday Inquirer, 15 November.

Horton, M. \& Freire, P. (1990) We Make the Road By Walking: Conversations on Education and Social Change (Philadelphia, PA: Temple University Press).

Merriam-Webster (1996-2003) Webster's Third New International Dictionary, Unabridged (electronic version).

Olwig, K. (1996) Recovering the substantive nature of landscape, Annals of the Association of American Geographers, 86(4), pp. 630-653.

Spirn, A. W. (1984) The Granite Garden: Urban Nature and Human Design (New York: Basic Books).

Spirn, A. W. (1985) Urban nature and human design: renewing the great tradition, Journal of Planning Education and Research, 5(1), pp. 39-51.

Spirn, A. W. (1986) Landscape planning and the city, Landscape and Urban Planning, 13, pp. 433-441.

Spirn, A. W. (1991) The West Philadelphia Landscape Plan: A Framework for Action (Philadelphia, PA: Department of Landscape Architecture, University of Pennsylvania). 
Spirn, A. W. (1998) The Language of Landscape (New Haven, CT: Yale University Press).

Spirn, A. W. (2000) Reclaiming common ground: water, neighborhoods, and public spaces, in: R. Fishman (Ed.) The American Planning Tradition: Culture and Policy (Washington, DC/Baltimore, MD: Woodrow Wilson Press/Johns Hopkins University Press).

Spirn, A. W. \& Cameron, M. (1991) Shaping the Block (Philadelphia, PA: Department of Landscape Architecture, University of Pennsylvania).

Spirn, A. W. \& Cheetham, R. (1996) The West Philadelphia Digital Database: An Atlas and Guide (Philadelphia, PA: Department of Landscape Architecture, University of Pennsylvania).

Spirn, A. W. \& Marcucci, D. (1991) Models of Success: Landscape Improvements and Community Development (Philadelphia, PA: Department of Landscape Architecture, University of Pennsylvania).

Spirn, A. W. \& Pollio, M. (1990) This Garden is a Town (Philadelphia, PA: Department of Landscape Architecture, University of Pennsylvania).

Spirn, A. W. \& Pollio, M. (1991) Vacant Land: A Resource for Reshaping Urban Neighborhoods (Philadelphia, PA: Department of Landscape Architecture, University of Pennsylvania). 